\title{
Vitamin B12 Deficiency
}

National Cancer Institute

\section{Source}

National Cancer Institute. Vitamin B12 Deficiency. NCI Thesaurus. Code C131684.

Low serum levels of vitamin B12 (cobalamin) due to poor intestinal absorption, decreased dietary intake, or increased physiologic requirement. 